УДК 784:792.7:001.8

Вероніка Іванівна Левко, кандидат мистецтвознавства, заступник декана факультету музичного мистецтва,

Київська муніципальна академія естрадного та циркового мистецтв, Київ, Україна

ORCID: 0000-0002-6946-0115

\title{
ДИХОТОМІЯ ІНДИВІДУАЛЬНОГО І КОЛЕКТИВНОГО У СОЛЬНОМУ ТА АНСАМБЛЕВОМУ ЕСТРАДНОМУ ВОКАЛЬНОМУ ВИКОНАВСТВІ
}

\begin{abstract}
Анотація. У дослідженні охарактеризовано особливості функціонування сольних i ансамблевих форм вокального мистецтва естради в іiі історичній динаміці. Методологія дослідження полягає в застосуванні історико-культурного, компаративного та аналітичного методів, які стали підгрунтям для цілісної характеристики сучасного естрадного виконавства в його сольному та ансамблевому різновидах. Було розглянуто сольне та ансамблеве естрадне виконавство у дихотомії індивідуального та колективного. Індивідуальне і колективне у вокальному мистецтві естради виявляються через взаємодію сольного та ансамблевого начал. Аналіз історичного розвитку світової вокальної естради дозволив виявити системну зміну у виконавських складах: кожне нове десятиріччя відзначено пріоритетністю або сольного, або ансамблевого співу. У 1970-х рр. на світовій естраді панує ансамблевий спів. Естетика вокальної насиченості в поєднанні з іміджем рок або поп-гурту як єдиного колективу сприяла культивуванню в естрадній музиці ансамблевого виконавства. 1980-і рр. стали періодом пріоритетності сольного співу на естраді, де вся увага концентрувалася на лідері колективу, функцію якого виконував
\end{abstract}


вокаліст. У цей період радикально змінюється естрадна естетика: ансамблевий спів трансформується в сольний як найбільш відповідний духу індивідуалізму. Еволюція форм вокального виконавства в естрадному мистецтві відбувається завдяки поступовій зміні ядра і периферії. Сольний спів народжується у надрах ансамблевого - індивідуалізація партій 3 часом призводить до виокремлення сольної, а усі інші втрачають значимість i набувають рис бек-вокалу. Цей перехідний тип співу ми окреслили як псевдо-ансамблевий, він історично передує трансформації виконавського складу. У добу пріоритетності сольного виконавства серед відомих естрадних артистів набувають популярності дуети та інші колективні форми естрадного співу, які свідчать про значимість для солістів-вокалістів ансамблевих форм.

Ключові слова: естрадне вокальне мистецтво, музичне виконавство, сольний спів, ансамблевий спів, рок-музика, попмузика, імідж, продюсування.

Вступ. Музична естрада як синтетичний вид мистецтва сьогодні має розвинену родову, видову та жанрову систему. Проте все розмаїття естрадних форм базується на перевазі у виконавстві сольного або ансамблевого начала. Відомо, що естрадний музичний гурт $\epsilon$ хорошим трампліном для накопичення концертного досвіду, i традиційно найталановитіші учасники музичних колективів із часом робили сольну кар'єру. 3 іншого боку, сольні артисти, особливо популярні, при виконанні музичних композицій часто поєднуються в дуети, тріо, квартети. 3 точки зору вокальної майстерності сольний і ансамблевий естрадний спів потребують різних навичок i мають різну естетику, проте обидва $\epsilon$ репрезентативними для естрадного мистецтва.

Постановка проблеми. Аналізуючи історичний розвиток естрадного мистецтва, ми бачимо, що попитом у публіки користуються і сольні естрадні артисти, і музичні 
(вокальні та вокально-інструментальні) колективи. Проте для аналізу загальних тенденцій розвитку світової та вітчизняної естради важливо встановити, чи було сольне або ансамблеве виконавство однаково популярним у різні часи, або ж $є$ певна закономірність у пріоритетності сольних та ансамблевих форм в історичному розвитку естрадного мистецтва в залежності від соціокультурних умов та запитів слухацької аудиторії. Аналіз пріоритетності сольних або ансамблевих форм дозволить не лише глибше усвідомити внутрішні механізми еволюції естрадного мистецтва, а й давати прогнози щодо можливих подальших процесів розвитку вокальної естради у майбутньому.

Аналіз останніх досліджень і публікацій. Естрадна музика сьогодні досліджується у різних аспектах - як феномен музичної культури України, у т. ч. в їі персоналістичних вимірах ([4], Т. Рябуха [5], Т. Самая [6], О. Сапожнік [7], О. Шевченко [9] та ін.), у контексті музичного виконавства і педагогіки ([1], Т. Ланіна [2], С. Чєрнікова [8]) та ін.). У науковій літературі вітчизняних дослідників сьогодні вже виокремлено специфічні риси сольного та ансамблевого естрадного співу як виконавської категорії. Т. Самая у дисертації робить детальний аналіз сучасної вокальної естетики естрадного виконавця. Дослідниця приділяє особливу увагу творчій індивідуальності сольного естрадного артиста. На їі думку, центральним компонентом звучання голосу співака $є$ його саунд, який «поєднує фізичні якості індивідуальної тембрації голосу та неповторну природу його звукової колористики. <..> Креативна сторона естетичної складової саунду естрадного співака полягає у компетенції в галузі електроніки та акустичної взаємодії, досвіді слухового діагностування звукоутворення, володінні колористикою звукових ефектів» $[6$, с. 170$]$. У роботі Т. Самая концентрує увагу майбутніх виконавців на пошуку власного індивідуального саунду, зосереджуючись на студійній роботі та переносячи напрацювання у студії звукозапису в концертну практику. Індивідуальність виконавця особливо важлива для 
дослідниці, оскільки вона апелює до традиції естрадного мистецтва 3 його пріоритетністю особистості артиста, що виступає на естраді, а не співака, який працює у шоу-бізнесі, де індивідуальність нівелюється, підлаштовуючись під той чи інший типаж.

В українській науці $є$ й напрацювання щодо специфіки ансамблевого естрадного співу. Особливе значення має дисертація С. Чєрнікової, присвячена саме цьому питанню. Дослідниця подає визначення естрадного вокального ансамблю, визначаючи його як унікальний художній організм, який «представляє особливу сферу функціонування музичного мистецтва естради i відрізняється якістю спільності, узгодженості, гармонії цілого і часткового, складання часток цього цілого і виникнення на його рівні нової якості, котра характеризується використанням голосів співаків, електроінструментів і звукопідсилювальної апаратури» [8, c. 10]. С. Чєрнікова розглядає специфіку звучання естрадного вокального ансамблю як збагачення вокальних партій через збільшення кількості вокалістів, що допомагає розширити об'єм фактури виконуваних творів. Тому центральним компонентом естрадного вокального виконавства стає колективна звучність, яка створюється за допомогою узгодженості та єдності, що виникає при поєднанні індивідуальних голосів і створює нову якість звучання. Нова ансамблева звучність відзначена новим тембром, оскільки в ній використано специфічні прийоми естрадного виконавства, серед яких інструментальне звучання голосу, субтон, фальцет, драйв [8, с. 13-14]. У процесі виконання музичного твору кожен учасник вокального ансамблю має подвійне завдання: по-перше, він має оволодіти формами колективного співу, де головним є акустичне злиття звуку, по-друге, він має максимально індивідуалізувати свою партію [8, с. 12].

Т. Ланіна продовжує розвивати основні положення, напрацьовані в галузі досліджень вокального естрадного 
виконавства. Вона розглядає естрадний вокальний ансамбль як цілісну систему, виявляючи їі структурні особливості. Т. Ланіна визначає його основні компоненти, до яких належать «1) виконавці (їх кількість обмежена - від двох до десяти); 2) музичний твір, що виконується; [3]) необхідний для виконання інструментарій» [3, с. 48]. Досліджуючи естрадний вокальний ансамбль у контексті комунікації, Т. Ланіна доходить висновку, що ансамблеве виконавство можна розглядати як специфічну форму комунікації, яка виявляється на мікро- й макрорівнях. У першому випадку це стосунки між учасниками ансамблю, де кожен $є$ індивідуальністю і вносить своє бачення у музичний твір, у другому - взаємодія між артистами ансамблю $і$ публікою [2, с. 68].

Тож констатуємо, що сьогодні питання вокального естрадного виконавства як культурно-мистецького явища в цілому вже розроблені. Тому виникає необхідність розгляду естрадного вокального виконавства в його двох іпостасях сольному та ансамблевому - як двох формах репрезентації вокальної естради, які є протилежними, але тісно пов'язаними між собою.

Мета статті - характеристика особливостей функціонування сольних $\mathrm{i}$ ансамблевих форм вокального мистецтва естради в іiї історичній динаміці.

Виклад основного матеріалу. Історія світової i вітчизняної естради знає безліч колективів та естрадних виконавців, творчість яких $\epsilon$ значним внеском у розвиток світової популярної музики. Проте чому хтось був відомим лише як учасник ансамблю і не зміг зробити сольної кар'єри, чи навпаки, чому творчість артиста стає значимою для естрадного мистецтва лише після того, як він покинув гурт і став сольним виконавцем? Сдиної відповіді на ці питання немає, але виявити певні закономірності цілком можливо.

Пріоритетність сольного або ансамблевого виконавства в естрадному мистецтві у той чи інший історичний період 
визначається багатьма чинниками, але одним 3 найважливіших $є$ очікування публіки: необхідність взаємодії зі слухачем орієнтує виконавців або їх продюсерів на пошук найвідповідніших артистів, які можуть стати зірками. Розглянемо цей аспект на прикладі світової популярної музики сер. 1950-х - поч. 1960-х рр. Неймовірний успіх американського співака Елвіса Преслі, який був зіркою рок-н-ролу, з початком «британського вторгнення», яке уособлював гурт «Бітлз», змінився прохолоднішим ставленням публіки до цього виконавця. Частково це можна пояснити зміною у музичному стилі, але однією з причин стала нова продюсерська стратегія, яка змінила виконавські пріоритети: продюсери стали віддавати перевагу не сольним виконавцям, а музичним колективам. Ера рок-музики в 1960-х рр. розпочала бум колективної творчості естрадних виконавців. 3 точки зору авторства вона якнайкраще відповідає музиці менестрельного типу, якою є рок, де всі учасники гурту одночасно $\epsilon$ і авторами, і виконавцями власної музики. Проте $\epsilon$ ще один аспект функціонування рок-гуртів, який $є$ природним, але потім він часто використовувався продюсерами. Всі учасники гурту отримували індивідуальний імідж відповідно до очкувань публіки. Якщо говорити про співака-соліста, то він зазвичай мав один образ-імідж, який робив його впізнаваним. Проте незмінність іміджу в подальшій кар'єрі виконавця з часом починала гальмувати творчість, роблячи його образ статичним. При роботі з музичним гуртом завдяки більшій кількості учасників іміджи всіх виконавців доповнювали один інший, чим i користувалися продюсери. Так, у випадку гурту «Бітлз» «кожен член колективу представляв певний генотип соціуму: Пол Маккартні втілював спокійний, врівноважений, інтелігентний образ; Джон Леннон - образ вольової, безкомпромісної людини; Рінго Старр мав образ типового «свого» хлопця, доброго і чуйного; Джордж Харрісон уособлював замкненість, зосередженість, романтизм» [6, с. 88]. Тому кожен шанувальник міг віднайти серед учасників гурту 
відповідний типаж, тим самим збільшуючи армію його прихильників.

У «золоту добу» рок-музики (1960-1970-ті рр.) більшість учасників як західних, так і радянських гуртів виконували функції і вокалістів, і інструменталістів. Тому вокальні партії у композиціях $\epsilon$ насиченими, зазвичай сольні заспіви доповнювалися ансамблевими приспівами. Естетика вокальної насиченості у поєднанні з іміджем гурту як єдиного колективу сприяла популярності рок-гуртів та культивуванню ансамблевого співу в естрадній музиці.

Якщо брати поп-музику 1970-і pp., то в ній також значиме місце посідав ансамблевий спів. Згадаймо найпопулярніші поп-гурти цих років - «АВBA» та «Boney M». Класичним поп-гуртом $\epsilon$ «АВВА», який $\epsilon$ вдалим проектом і 3 точки зору поп-музики, яка на сьогодні вже $\epsilon$ класичною, і 3 точки зору складу гурту. У склад «АВВА» входили два чоловіки (Бенні Андерссон, Бйорн Ульвеус) і дві дівчини (Анні-Фрід Люнгстад, Агнета Фельтскуг), які іміджем та вокалом доповнювали одна одну (сопрано Агнета Фельтскуг є білявкою, а мецо-сопрано Анні-Фрід Люнгстад - шатенкою). На сцені солістки гурту «АВВА» завдяки контрастній зовнішності взаємодоповнювали одна одну, у вокальному відношенні їх дует звучав злагоджено завдяки теситурній та тембровій різниці. Варто відзначити, що і Агнета Фельтскуг, і Анні-Фрід Люнгстад до утворення i після розпаду «АВВА» випускали сольні альбоми, які користувалися популярністю серед слухачів, але які, все ж, не могли зрівнятися 3 музичною творчістю, представленою шалено популярним гуртом «АВВА». Вартий уваги і той унікальний факт, що протягом усього часу існування колективу його склад не змінювявся, оскільки завдяки ансамблевому співу, гармонійності у співвідношенні голосів та вдалому іміджу була знайдена ідеальна модель естрадного ансамблю, де кожен учасник був індивідуальністю, тому існування гурту не мислилося 3 іншими виконавцями. Завдяки 
співвідношенню індивідуального та унікального гурт «АВВА» став одним 3 найкращих колективів у світовій популярній музиці. Як аналогію наведемо й легендарний гурт «Бітлз», який також був ідеальним колективним утворенням. Після його розпаду музиканти мали власні сольні проекти, які були вдалими, але ця популярність базувалася на відблиску слави легендарного гурту, що у свій час, як колись сказав в інтерв'ю Дж. Леннон, був популярніший за Ісуса.

Іншу картину ми бачимо у гурту «Boney М». Колектив був утворений продюсером Френком Фаріаном фактично як віртуальний - у записі перших пісень взяли участь анонімні музиканти. Проте популярність пісень стали причиною того, що гурт, класичний склад якого мав чотирьох музикантів (три солістки та соліст), з віртуального став реальним. У різні роки у складі колективу були співачки Мейзі Вільямс, Шейла Боннік, Марсія Барретт, Клавдія Беррі, Ліз Мітчелл та співаки Боббі Фарелл, Реджи Цибо. Найбільш знаною учасницею гурту була Ліз Мітчелл, яка сьогодні $є$ сольною виконавицею. Співачка виконує свої пісні, але має право виступати під брендом «Boney М», виконуючи найкращі хіти цього легендарного гурту.

«Boney $\mathrm{M»-} \mathrm{це} \mathrm{передусім} \mathrm{продюсерський} \mathrm{проект,} \mathrm{i}$ вокалісти з вокалістками для студійного запису та концертної діяльності підбиралися спеціально. Тому говорити про індивідуальність виконавців як учасників єдиного ансамблю, що створюють не лише вокальну, а й духовну єдність, не можна. 3 точки зору технології вокальна майстерність гурту «Boney M» $\epsilon$ бездоганною, але ми бачимо певну пріоритетність солістки, якою була Ліз Мітчелл, інші виконавиці скоріше були беквокалістками, ніж повноправними учасницями вокального ансамблю. Така модель мала певні пріоритети: сольна партія «трималася» на найпотужнішій вокалістці, інші співачки виконували функцію бек-вокалу, а також своєю присутністю заповнювали собою сцену. 3 точки зору іміджу вони контрастували провідній солістці, одночасно створюючи єдиний 
естетичний простір. Такого роду гурти формально культивували ансамблевий спів, але він був скоріше псевдо-ансамблевим, оскільки пріоритетність мав сольний спів, який прикрашався бек-вокалом. Партії учасниць або учасників, що фактично підспівували солістці, не були індивідуалізовані, і тому у цьому випадку не можна говорити про ансамблевий спів у його класичному розумінні.

Життя гуртів 3 псевдо-ансамблевим співом тривало до тих пір, коли у ньому працювали провідний соліст або солістка, 3 його уходом проект переставав існувати. Зміна учасників із функцією бек-вокалістів зазвичай не впливала на життя гурту. Як приклад наведемо популярний німецький жіночий поп-гурт «Арабески» («Arabesque»), який на початку кілька разів змінював склад учасників. У 1979 р. до гурту входить Сандра Лауер, яка перебирає функції провідної солістки. Протягом її п'ятирічного контракту гурт набирає популярності, але після іiі уходу він розпадається. Дві інші учасниці «Арабесок», Міхаела Роуз та Жасмин Феттер, спробували створити свій власний гурт, проте він успіху не мав. Сандра Лауер, яка відтоді виступає під ім'ям Сандра, зробила блискучу кар'єру, яка триває й донині. Ще одним прикладом може стати кар'єра британського співака Гордона Метью Томаса Самнера, відомого під псевдонімом Стінг (Sting). Співак з 1976 по 1984 рр. був учасником британського гурту «The Police», після чого розпочав власну кар'єру. Після уходу Стінга 3 колективу гурт розпадається, але співак, виступаючи як сольний артист, $є$ одним 3 найпопулярніших виконавців у світі.

Серед українських виконавців наведемо приклад Софії Ротару, яка розпочала свою кар'єру на початку 1970-х рр. як вокалістка гурту «Червона рута». Цікаво, що частину репертуару ансамбль виконував окремо як самостійна творча одиниця, де превалював класичний для тих часів ансамблевий спів. У композиціях, які виконувала С. Ротару, ансамбль «Червона рута» міняв свою функцію, перетворюючись у 
колектив, що лише супроводжує спів головної солістки. У 1980-х рр. співачка, яка на той час стала відомою, розпочинає сольну кар'єру, а ансамбль «Червона рута», хоча і продовжує виступати, втрачає пріоритетні позиції на естраді.

Узагальнимо зазначені спостереження. У 19601970-х рр. на світовій естраді культивується ансамблевий спів, відповідно, важливе місце у культурно-мистецькому просторі посідають рок- та поп-гурти. Популярність ансамблевого виконавства мала кілька причин, дві з яких лежали в мистецький площині (колективна творчість рок-гуртів, акцент на вокалі у його повноті, яка може бути представлена лише у багатоголоссі), третя - у продюсерській (кількість музикантів у колективі має бути постійною, і кожен 3 них повинен мати окремий імідж, спрямований на певну частину слухацькоглядацької аудиторії). У сер. 1970-х рр. починає переважати продюсерська складова, коли гурти вже формуються під конкретну цільову групу. Створення нових проектів іде не від музичного компоненту, а від іміджу колективу. Вокальне мистецтво як узгодженість голосів відходить на другий план, $\mathrm{i}$ ансамблевий спів поступово трансформується в сольний: з'являються гурти, де соліст або солістка концентрують у собі мелодичне начало, інші учасники або учасниці гурту стають бек-вокалістами. Результатом цих процесів стали сольні проекти колишніх лідерів поп- або рок-гуртів, де вони мали можливість продемонструвати себе як виконавську індивідуальність.

1980-і pp. - період сольного виконавства на естраді, коли індивідуальність проявляється не в ансамблевому співі учасників вокальної групи, а в сольному самовираженні єдиного лідера усього виконавського колективу. Це не означає, що в цей час відсутні гурти як виконавські одиниці, але в цей період радикально змінюється естрадна естетика, і ансамблевий спів зазнає глибинних трансформацій: віднині на естраді панує принцип індивідуалізму. Поп- i рок-гурти продовжують 
утворюватися й надалі, але класичного багатоголосся, яке було у 1960-1970-х рр. на естраді, вже немає.

У 1990-і та на поч. 2000-х рр. знову виникає інтерес до гуртів, які відроджують вокальні традиції тридцятирічної давнини. Серед таких колективів назвемо «Backstreet Boys», «NSYNC», «TLC» та ін. Ці гурти за доби реп-музики звернулися до вокалу як до підвалин естрадного музичного мистецтва. Проте індивідуалізація у гуртах цих років відбувалася в інший спосіб, ніж це було раніше: виконавський акцент ставився не на єднанні всіх голосів в ансамблі, хоча це теж було закладено в естетиці цих творів, а на презентації кожного учасника колективу, який мав хоч невелике, але власне соло у композиції. Кожен 3 учасників гурту мав свій артистичний індивідуальний типаж, але артистам з таких проектів рідко вдавалося зробити успішну сольну кар'єру. Так, жоден учасників популярного гурту «Backstreet Воуs» не зробив вдалої сольної кар'єри. Винятком $є$ Джастін Тімберлейк - колишній учасник «NSYNC», який сьогодні $\epsilon$ одним 3 найвідоміших поп-музикантів. Аналогічну картину ми бачимо i в денс-гуртах, серед яких найпопулярнішим у 1990-х pp. став британський колектив «Spice Girls». Кожна учасниця колективу мала власний імідж: у пресі вони фігурували під власними прізвиськами Пош-Спайс (Вікторія Адамс), Бебі-Спайс (Емма Бантон), Спорті-Спайс (Мелані Чісхолм), Скері-Спайс (Мелані Браун) і ДжинджерСпайс (Джері Холлівелл). Остання $з$ учасниць «Spice Girls» у 1998 р. першою вирішила покинути гурт заради сольної кар'єри, пізніше після розпаду гурту всі учасниці почали виступати як солістки, але жодна 3 них не змогла зрівнятися популярністю 3 гуртом «Spice Girls». Характерно, що спроби почати сольну кар'єру припадають на злам століть або на поч. 2000-х рр. Таким чином, якщо в 1990-і pp. триває повернення до ансамблевого співу, хоча і в новій формі, то у 2000-х рр. знову стає актуальним сольний спів. Насиченість звуку у сольних артистів створюється за рахунок бек-вокалу, без якого важко 
уявити сучасну естраду. Проте 3 точки зору класичного ансамблевого співу 3 його індивідуалізацією голосів сьогоднішня естрада є суттєво відмінною від класичних зразків 1960-1970-х pp.

Загалом еволюція вокального естрадного виконавства відбувається як постійна зміна виконавських пріоритетів, актуальність яких триває приблизно одне десятиліття. Ансамблевий спів змінюється сольним, сольний - ансамблевим, при цьому кожен наступний виток дає нову версію сольного або вокального виконавства. Може скластися враження, що з часом сольний спів витіснить ансамблевий, і солісти будить співати лише з бек-вокалістами. Проте практика показує інше - сьогодні солісти об'єднуються в дуети, і серед багатьох номінацій численних музичних премій обов'язковою $\epsilon$ дуетний спів. Сучасний дует не завжди передбачає класичний ансамблевий спів, оскільки часто разом виконаються пісні естрадний співак із реп-виконавцем. Проте саме звертання солістів до спільного виконавства свідчить про те, що колективне музикування $\epsilon$ формою, які ніколи не втратить актуальності.

Висновки. Індивідуальне i колективне у вокальному мистецтві естради виявляються через взаємодію сольного та ансамблевого начал. Аналіз історичного розвитку світової вокальної естради дозволив виявити системну зміну у виконавських складах: кожне нове десятиріччя відзначено пріоритетністю або сольного, або ансамблевого співу. У 1970-х рр. на світовій естраді панує ансамблевий спів. Естетика вокальної насиченості в поєднанні з іміджем рок- або поп-гурту як єдиного колективу сприяла культивуванню в естрадній музиці ансамблевого виконавства. 1980-і рр. стали періодом пріоритетності сольного співу на естраді, де вся увага концентрувалася на лідері колективу, функцію якого виконував вокаліст. У цей період радикально змінюється естрадна естетика: ансамблевий спів трансформується в сольний як найбільш відповідний духу індивідуалізму. Еволюція форм 
вокального виконавства в естрадному мистецтві відбувається завдяки поступовій зміні ядра i периферії. Сольний спів народжується у надрах ансамблевого - індивідуалізація партій із часом призводить до виокремлення сольної, а усі інші з часом втрачають значимість i набувають рис бек-вокалу. Цей перехідний тип співу ми окреслили як псевдо-ансамблевий, він історично передує трансформації виконавського складу. За доби пріоритетності сольного виконавства серед відомих естрадних артистів набувають популярності дуети та інші колективні форми естрадного співу, які свідчать про значимість для солістів-вокалістів ансамблевих форм.

\section{Лiтература}

1. Дрожжина Н. Вокальне виконавство у системі музичного мистецтва естради: дис. ... канд. мистецтвознавства: 17.00 .03 «Музичне мистецтво». Харків, 2008. 186 с.

2. Ланіна T. Теоретичні основи вокального ансамблевого виконавства // Музичне мистецтво в освітологічному дискурсі. 2017. № 2. Сc. 46-50.

3. Ланіна T. Феномен естрадного вокального ансамблю в сучасному культурному просторі // Мистецтвознавчі записки. 2017. Вип. 31. Сс. 64-69.

4. Мозговий М. Становлення і тенденції розвитку української естрадної пісні: дис. ... канд. мистецтвознавства: 17.00.01 - «Теорія та історія культури». Київ, 2007. 175 с.

5. Рябуха T. Витоки та інтонаційні складові української пісенної естради: дис. ... канд. мистецтвознавства: 17.00 .03 «Музичне мистецтво». Харків, 2017. 203 с.

6. Самая T. Вокальне мистецтво естради як чинник культурного життя України другої половини XX - початку XXI століття: дис. ... канд. мистецтвознавства: 26.00.01 «Теорія та історія культури». Київ, 2017. 199 с. 
7. Сапожнік $O$. Антологія української популярної естрадної музики: навч. посіб. Київ: ДАКККіМ, 2003. Ч. 1. 165 с. Ч. $2.152 \mathrm{c}$.

8. Чернікова C. Генеза естрадного вокально-ансамблевого виконавства та шляхи його професіоналізації: автореф. дис. ... канд. мистецтвознавства: 17.00.03 - «Музичне мистецтво». Харків, 2008. 19 с.

9. Шевченко О. Українська популярна музика: витоки та проблематика (1920-1990 рр.): автореф. дис. ... канд. мистецтвознавства: 26.00.01 - «Теорія та історія культури». Київ, 2010. 19 с.

\title{
Вероника Ивановна Левко,
} кандидат искусствоведения, заместитель декана факультета музыкального искусства, Киевская муниципальная академия эстрадного и циркового искусств, Киев, Украина ORCID: 0000-0002-6946-0115

\section{ДИХОТОМИЯ ИНДИВИДУАЛЬНОГО И КОЛЛЕКТИВНОГО В СОЛЬНОМ И АНСАМБЛЕВОМ ЭСТРАДНОМ ВОКАЛЬНОМ ИСПОЛНИТЕЛЬСТВЕ}

\begin{abstract}
Аннотация. В исследовании охарактеризованы особенности функционирования сольных и ансамблевых форм вокального искусства эстрады в ее исторической динамике. Методология исследования заключается в применении историко-культурного, сравнительного и аналитического методов, которые стали основой для целостной характеристики современного эстрадного исполнительства в его сольной и ансамблевой разновидностях. Были рассмотрены сольное и ансамблевое эстрадное исполнительство в дихотомии
\end{abstract}


индивидуального и коллективного. Индивидуальное и коллективное в вокальном искусстве эстрады проявляются через взаимодействие сольного и ансамблевого начал. Анализ исторического развития мировой вокальной эстрады позволил выявить системную смену в исполнительских составах: каждое новое десятилетие отмечено приоритетностью или сольного, или ансамблевого пения. В 1970-х гг. на мировой эстраде господствует ансамблевое пение. Эстетика вокальной насыщенности в сочетании с имиджем рок- или поп-группы как единого коллектива способствовала культивированию в эстрадной музыке ансамблевого исполнительства. 1980-е гг. стали периодом приоритетности сольного пения на эстраде, где все внимание концентрировалось на лидере коллектива, функцию которого исполнял вокалист. В этот период радикально меняется эстрадная эстетика: ансамблевое пение трансформируется в сольное как наиболее соответствующее духу индивидуализма. Эволюция форм вокального исполнительства в эстрадном искусстве происходит благодаря постепенной смене ядра и периферии. Сольное пение рождается в недрах ансамблевого - индивидуализация партий со временем приводит к выделению сольной, а все остальные теряют значимость и приобретают черты бэк-вокала. Этот переходный тип пения мы обозначили как псевдо-ансамблевый, он исторически предшествует трансформации исполнительского состава. В эпоху приоритетности сольного исполнительства среди известных эстрадных артистов приобретают популярность дуэты и другие коллективные формы эстрадного пения, которые свидетельствуют о значимости для солистоввокалистов ансамблевых форм.

Ключевые слова: эстрадное вокальное искусство, музыкальное исполнительство, сольное пение, ансамблевое пение, рок-музыка, поп-музыка, имидж, продюсирование. 


\author{
Veronica I. Levko, \\ $\mathrm{PhD}$ in Arts, \\ Deputy Dean of the Faculty of Musical Art, \\ Kyiv Municipal Academy of Circus and Variety Arts, \\ Kyiv, Ukraine
}

\title{
DICHOTOMY OF INDIVIDUAL AND COLLECTIVE IN SOLO AND ENSEMBLE VARIETY VOCAL PERFORMANCE
}

\begin{abstract}
The study describes the functioning of solo and ensemble forms of vocal variety art in its historical dynamics. The research methodology is based on the application of historical, cultural, comparative and analytical methods, which became the basis for the holistic characteristics of modern variety performing in its solo and ensemble versions. The scientific novelty of the work lies in the fact that for the first time in Ukrainian science solo and ensemble variety performing in the dichotomy of individual and collective were considered. Individual and collective in variety vocal art are manifested through the interaction of solo and ensemble principles. An analysis of the historical development of the world vocal stage has revealed a systemic change in the performing compositions: each new decade is marked by the priority of either solo or ensemble singing. In the 1970s ensemble singing dominates the world stage. The aesthetics of vocal richness, combined with the image of a rock or pop group as a single collective, contributed to the cultivation of ensemble performance in pop music. 1980s became a period of priority for solo singing on the stage, where all attention was concentrated on the leader of the collective, whose function was performed by the vocalist. During this period, pop aesthetics radically changed: ensemble singing was transformed into solo as the most appropriate to the spirit of individualism. The evolution of forms of vocal performance in variety art is due to the gradual change of core and periphery. Solo singing is born in the bowels of
\end{abstract}


the ensemble - individualization of parts over time leads to the release of solo, and all the others eventually lose their significance and acquire the features of backing vocals. We designated this transitional type of singing as pseudo-ensemble, it historically precedes the transformation of the performing staff. In the era of the priority of solo performance among famous pop artists, duets and other collective forms of variety singing are gaining popularity, which indicate the importance of ensemble forms for solists vocalists.

Key words: variety vocal art, musical performance, solo singing, ensemble singing, rock music, pop music, image, producing.

\section{References}

1. Drozhzhina N. Vokal'ne vykonavstvo u systemi muzychnoho mystetstva estrady [Vocal performance in the music variety art]. Candidate's thesis. Kharkiv, 2008. 186 s. (in Ukrainian)

2. Lanina T. Teoretychni osnovy vokal'noho ansamblevoho vykonavstva [Theoretical basis of vocal ensemble performance]// Muzychne mystetstvo v osvitologichnomu dyskursi. 2017. №2. Ss. 46-50 (in Ukrainian)

3. Lanina T. Fenomen estradnogo vokal'nogo ansamblyu v suchasnomu kul'turnomu prostori [The phenomenon of a variety vocal ensemble in contemporary cultural space]// Mystetstvoznavchy zapysky. 2017. №31. Ss. 64-69 (in Ukrainian)

4. Mozhovyy M. Stanovlennya i tendentciyi rozvytku Ukrayins'koyi estradnoyi pisni [Formation and tendencies of development of Ukrainian pop songs]. Dis. kand. mystetsvoznav. Kyiv, 2007. 175 s. (in Ukrainian)

5. Ryabukha T. Vytoky ta intonaciyni skladovi ukrayins'koyi pisennoyi estrady [Origins and intonational components of the Ukrainian song variety]. Dis. kand. mystetsvoznav. Kharkiv, 2017. 203 s. (in Ukrainian)

6. Samaya T. Vokal'ne mystetstvo estrady yak chynnyk kul'turnogo zhyttya Ukrayiny drughoyi polovyny XX - pochatku 
XXI stolittya [The variety vocal art as a factor in the cultural life of Ukraine in the second half of the $20^{\text {th }}-$ beginning of the $21^{\text {st }}$ century]. Dis. kand. mystetsvoznav. Kyiv, 2017. $199 \mathrm{~s}$. (in Ukrainian)

7. Sapozhnik $O$. Antologiya ukrayins'koyi populyarnoyi estradnoyi muzyky [Anthology of Ukrainian popular variety music]. Textbook. Ch. 1. 165 s. Ch. 2. 152 s. Kyiv: DAKKKiM, 2003. (in Ukrainian)

8. Chyernikova S. Geneza estradnoho vokal'no-ansamblevoho vykonavstva ta shlyakhxy yoho profesionalizaciyi [Genesis of the pop vocal-ensemble performance and ways of professionalization]. Avtoref. dis. kanf. mystetstvoznav. Kharkiv, 2008. 19 s. (in Ukrainian)

9. Shevchenko $O$. Ukrayins'ka populyarna muzyka: vytoky ta problematyka (1920-1990 rr.): [Ukrainian popular music: origins and perspectives (1920-1990s)]. Avtoref. dis. kanf. mystetstvoznav. Kyiv, 201019 s. (in Ukrainian) 